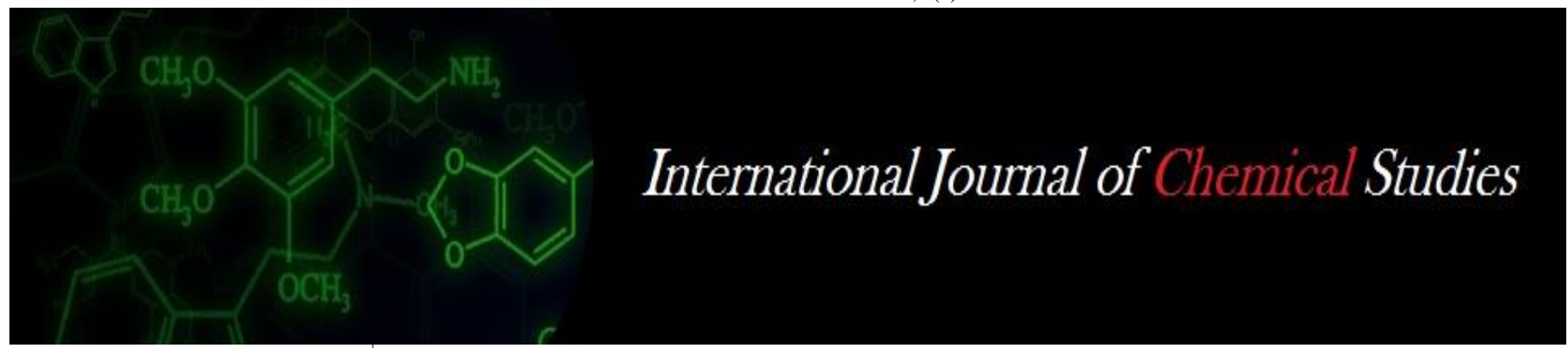

P-ISSN: 2349-8528

E-ISSN: 2321-4902

www.chemijournal.com

IJCS 2020; 8(4): 2506-2509

(C) 2020 IJCS

Received: 10-05-2020

Accepted: 12-06-2020

Pooja Srivastav

M.Sc. Scholar, Department of

Agronomy, College of

Agriculture, Rajendranagar,

PJTSAU, Hyderabad,

Telangana, India

Ch. Bharat Bhushan Rao Associate Professor, Department of Agronomy, Students farm, College of Agriculture,

Rajendranagar, PJTSAU,

Hyderabad, Telangana, India

T Ram Prakash

Principal Scientist, Department of SSAC, AICRP on Weed

Management, Rajendranagar, PJTSAU, Hyderabad,

Telangana, India

Syed Ahmed Hussain

Professor, Department of

Agronomy, College farm, College

of Agriculture, Rajendranagar,

PJTSAU, Hyderabad,

Telangana, India
Corresponding Author: Pooja Srivastav

M.Sc. Scholar, Department of

Agronomy, College of

Agriculture, Rajendranagar,

PJTSAU, Hyderabad,

Telangana, India

\section{Response of different iron sources on yield attributes and yield of pearlmillet cultivars}

\author{
Pooja Srivastav, Ch. Bharat Bhushan Rao, T Ram Prakash and Syed \\ Ahmed Hussain
}

DOI: https://doi.org/10.22271/chemi.2020.v8.i4ac.10009

\begin{abstract}
An investigation on "Response of different iron sources on yield attributes and yield of pearlmillet cultivars" was carried out during kharif season 2019 at College of Agriculture, Rajendranagar. The experiment comprised of two cultivars of bajra as main plot treatments and five iron sources as subplot treatments tested under split plot design with 10 treatments and each treatment replicated three times. Pearlmillet hybrids PBH-1625 and HHB-67 were grown by adopting recommended package of practices. Higher yield attributes and yield were observed in PBH-1625 cultivar. Plant nutrients applied through inorganic fertilizer and in combinations with organic manures or iron sources showed significant effect on yield attributes and yield in different treatments. Application of iron through enriched FYM resulted in increased yield attributes and yield of pearl millet with $\mathrm{T}_{3}\left(\mathrm{FeSO}_{4}\right.$ fortified manure @ $\left.500 \mathrm{~kg} \mathrm{ha}^{-1}\right)$ treatment.
\end{abstract}

Keywords: Pearlmillet, iron sources, hybrids, yield attributes and yield

\section{Introduction}

Pearl millet (Pennisetum glaucum L.) is the most widely grown type of millet. Though it is not one of the world's most abundant or widely consumed grains, pearl millet does provide a major food, staple for millions of people in the western parts of India and in Africa. Pearl millet and other millet grains survive in arid, hot environments in which more widely used cereal grains would not thrive. Hence, its production and importance is growing concurrently with global warming.

Bajra is a significant source of iron and zinc and has been shown to account for $19-63 \%$ of the total iron and $16-56 \%$ of total zinc intake from all food sources in pearl millet growing states of Maharashtra, Gujarat and Rajasthan in India (ICRISAT) ${ }^{[1]}$. It is also the cheapest source of these micronutrients as compared to other cereals and vegetables. Thus pearl millet bio fortification opens up the possibility of a cost-effective strategy to beat malnutrition in women and children while simultaneously providing smallholder farmers a climate-ready crop to face the vagaries of climate change.

According to WHO [2], anaemia affects nearly 1.62 billion people ( $24.8 \%$ of the population) globally. Iron deficiency causes varying degrees of impairment in cognitive performance and learning ability, lowered work capacity and pregnancy complications e.g., maternal mortality and babies with low birth weight (Kedar, 2017) ${ }^{[3]}$. Bio fortification is a process of increasing the micronutrient content of staple crops through plant breeding, transgenic techniques or agronomic practices. This technology is essential to improve nutrition quality by agricultural based strategies for poor farmers who solely rely on this crop. Bio fortified staple crops when consumed regularly will generate measurable improvements in human health and nutrition. In the case of iron, WHO estimated that Bio fortification could help curing the two billion people suffering from Iron deficiency induced anaemia. According to the study, recently published in the Journal of Nutrition, bio fortified high-iron pearl millet can stem the deleterious effect of iron deficiency by significantly improving nutrition and cognitive performance (Samuel et al., 2018) ${ }^{[4]}$. Since information pertaining to above aspects is meager and keeping the above facts under consideration, the present experiment was conducted to study the influence iron sources on bajra cultivars growth, yield and economics of pearl millet. 


\section{Material and Methods}

The experiment was carried out in research farm of College of Agriculture, Rajendranagar during kharif- 2019. The soil of experimental plot was sandy loam in texture with slightly alkaline in nature, low in organic carbon, low in available nitrogen, medium in phosphorus and potassium and low in iron. The pearl millet cultivars were sown with $45 \mathrm{~cm}$ of row spacing. The experiment was designed with two cultivars as main plot treatment and five iron sources as subplot laid out in split plot design with three replications. The $60 \mathrm{~kg} \mathrm{~N}, 30 \mathrm{~kg}$ $\mathrm{P}_{2} \mathrm{O}_{5}$ and $20 \mathrm{~kg} \mathrm{~K} 2 \mathrm{O}$ per hectare was recommended dose for pearl millet. Half dose of the $\mathrm{N}$ was applied as basal and remaining quantity of nitrogen was top dressed at 30 DAS. The complete doses of $\mathrm{P}$ and $\mathrm{K}$ were applied at the time of sowing. As per treatment, control was treated only with recommended dose of NPK, without any iron source. Iron was applied through iron sulphate basally in $\mathrm{T}_{2}$, iron sulphate fortified manure prepared by fortification of farm yard manure @ $500 \mathrm{~kg} \mathrm{ha}^{-1}$ and iron sulphate @ $25 \mathrm{~kg} \mathrm{ha}^{-1}$ fermented for 21 days in $\mathrm{T}_{3}$, foliar application of iron (before and after flowering) as per treatments @ $0.5 \%$ iron sulphate and $0.2 \%$ Fe-EDTA in $\mathrm{T}_{4}$ and $\mathrm{T}_{5}$ treatments respectively.

Five plants were selected at random from net plot area and labelled with tags. At harvest, tagged plants were sampled from net plot area of each treatment plot to observe yield attributes. The grain and stover yield from net plot area including sampled plants were thoroughly sun dried, weighed and expressed in $\mathrm{kg} \mathrm{ha}^{-1}$. Data on yield attributes and yield of pearl millet were statistically analyzed duly following the analysis of variance technique for split plot design as suggested by Panse and Sukhatme (1978) [5]. Statistical significance was tested with $\mathrm{F}$ test at 0.05 level of probability and where ever the $\mathrm{F}$ value was found significant, critical difference (CD) was worked out to test the significance.

\section{Results and Discussion Yield attributes}

Cultivar PBH-1625 registered highest record on yield attributes viz., earhead length, earhead girth, number of grains earhead $^{-1}$, grain weight earhead ${ }^{-1}$ and test weight compared to HHB-67. Interaction effect of cultivars and iron sources on yield attributes of pearl millet was found to be nonsignificant.

Between cultivars better partitioning of photosynthates from source to sink might have resulted in higher length and girth of ear head which might be due to the genetic makeup of the hybrid. Similar results were confirmed by Yadav et al. (2003) ${ }^{[6]}$, Kumar et al. (2004) ${ }^{[7]}$ and Chaudhari et al. (2018) ${ }^{[8]}$. The increase in the number of grains per ear head was due to increase in length and girth of panicle. Similar finding was observed by Prasad et al. (2014) [9]. Significantly better development of source in form of dry matter accumulation, might have contributed to the more grain weight per ear head (Divya and Vani, 2019) ${ }^{[10]}$. Test weight is mainly controlled by genetic makeup of the cultivars. Higher test weight of PBH-1625 might be attributed to increase in transformation of assimilates in grain and subsequent development of more bold seeds resulting in higher test weight. These results also substantiate the findings of Yadav et al. (2014) ${ }^{[11]}$ and Chaudhari et al. (2018) ${ }^{[8]}$.

Earhead length, earhead girth, number of grains ear head ${ }^{-1}$, grain weight earhead ${ }^{-1}$, were maximum under $\mathrm{T}_{3}$ (iron fortified manure) treatment followed by RDF+ Fe-EDTA spray @ $0.2 \%$ applied two times i.e. before and after flowering. Better nutrition due to application of fertilizers along with iron treatments and fortified FYM might have resulted into better root growth and development, enhanced nutrient availability, uptake and translocation and thus increasing the earhead length and girth. The results obtained were in accordance with those of Bana et al. (2016) [12], Nikhil and Salakinkop (2018) ${ }^{[13]}$. Increase in number of grains per ear head and grain weight with application of iron sources and fortified FYM might be attributed to overall improvement in vigour and crop growth by producing chelating agents which improves the utilising efficiency of macro and micronutrients. Similar result was also reported by Nikhil and Salakinkop (2018) ${ }^{[13]}$.

\section{Yield}

Between the cultivars significantly maximum grain yield $\left(3766 \mathrm{~kg} \mathrm{ha}^{-1}\right)$, stover yield $\left(6454 \mathrm{~kg} \mathrm{ha}^{-1}\right)$ and harvest index (36.9\%) was observed with PBH-1625 over HHB-67.

Among the iron treatments $\left(\mathrm{T}_{3}\right)$ iron fortified manure yielded significantly maximum grain yield (3542 $\left.\mathrm{kg} \mathrm{ha}^{-1}\right)$ and stover yield $\left(6099 \mathrm{~kg} \mathrm{ha}^{-1}\right)$ followed by RDF+ Fe-EDTA spray @ $0.2 \%$ applied two times i.e. before and after flowering. Interaction effect of cultivars and iron sources were found to be non-significant.

Difference in yields (grain + stover) between the cultivars might be attributed due to better response of hybrid PBH1625 over the other resulting in increased number of effective tillers, better ear head length, girth and more number of grains with higher test weight. Significantly better development of source in the form of dry matter accumulation, had contributed to the more yield attributes and higher yield. The difference in the yield and yield attributes may also be attributed due to their genetic constitution. Similar results were also reported by Satyajeet et al. (2007) ${ }^{[14]}$, Choudhari et al. (2018) ${ }^{[8]}$ and Divya and Vani (2019) ${ }^{[10]}$. The variation in harvest index among the cultivars might be due to difference in partitioning efficiency of photosynthates from source to sink. These observations corroborate with those made by Yadav et al. (2004) ${ }^{[15]}$.

Among the iron treatments, fortified manure application increased yield (grain + stover) which might also be due to improved availability of micronutrient $(\mathrm{Fe})$ which could be attributed to the formation of stable organometallic complexes of iron with FYM, especially during enrichment process to last for a longer time and release nutrients slowly in soil system in such a way that nutrients are protected from fixation and made available to plant throughout crop growth. These observations corroborate with those made by Bandiwaddar and Patil (2015) ${ }^{[16]}$, Nikhil and Salakinkop (2018) ${ }^{[13]}$. 
Table 1: Yield attributes of bajra hybrids as influenced by iron sources

\begin{tabular}{|c|c|c|c|c|c|}
\hline Treatment & \begin{tabular}{|c} 
Earhead \\
length \\
$(\mathrm{cm})$
\end{tabular} & $\begin{array}{l}\text { garhead } \\
\text { girth } \\
(\mathrm{cm})\end{array}$ & $\begin{array}{c}\text { No. of } \\
\text { grains } \\
\text { earhead }^{-1} \\
\end{array}$ & $\begin{array}{c}\text { Grain } \\
\text { weight } \\
\text { earhead }^{-1}(\mathrm{~g})\end{array}$ & \begin{tabular}{|c|}
$\begin{array}{c}\text { Test } \\
\text { weight } \\
(\mathrm{g})\end{array}$ \\
\end{tabular} \\
\hline \multicolumn{6}{|l|}{ Hybrids (Main plot) } \\
\hline PBH-1625 & 26.3 & 10.5 & 3987 & 39.2 & 10.5 \\
\hline HHB-67 & 20.3 & 7.6 & 1706 & 15.2 & 8.6 \\
\hline SEm \pm & 0.5 & 0.1 & 61 & 0.6 & 0.2 \\
\hline $\mathrm{CD}(\mathrm{P}=0.05)$ & 3.6 & 0.9 & 401 & 4.2 & 1.2 \\
\hline \multicolumn{6}{|l|}{ Iron sources (Subplot) } \\
\hline Control (RDF) & 21.7 & 8.4 & 2654 & 23.6 & 9.2 \\
\hline $\mathrm{RDF}+50 \mathrm{~kg} \mathrm{ha}^{-1}$ of $\mathrm{FeSO}_{4}$ applied to soil as basal & 22.6 & 8.8 & 2757 & 26.6 & 9.4 \\
\hline RDF+ FeSO4 fortified manure @ $500 \mathrm{~kg} \mathrm{ha}^{-1}$ & 25.4 & 9.9 & 3120 & 30.3 & 10.0 \\
\hline $\mathrm{RDF}+\mathrm{FeSO}_{4}$ spray ( $0.5 \%$ foliar spray applied two times i.e. before and after flowering) & 23.1 & 9.1 & 2772 & 27.1 & 9.6 \\
\hline RDF+ Fe-EDTA spray (0.2\% foliar spray applied two times i.e. before and after flowering) & 23.6 & 9.2 & 2928 & 28.4 & 9.8 \\
\hline SEm \pm & 0.6 & 0.2 & 61 & 0.7 & 0.2 \\
\hline $\mathrm{CD}(\mathrm{P}=0.05)$ & 1.7 & 0.6 & 184 & 2.0 & NS \\
\hline \multicolumn{6}{|l|}{ Hybrids x Iron sources } \\
\hline \multicolumn{6}{|l|}{ Sub at same main } \\
\hline SEm \pm & 1.2 & 0.3 & 137 & 1.4 & 0.4 \\
\hline $\mathrm{CD}(\mathrm{P}=0.05)$ & NS & NS & NS & NS & NS \\
\hline \multicolumn{6}{|l|}{ Main at same or different sub } \\
\hline $\mathrm{SEm} \pm$ & 0.9 & 0.3 & 98 & 1.1 & 0.3 \\
\hline $\mathrm{CD}(\mathrm{P}=0.05)$ & NS & NS & NS & NS & NS \\
\hline
\end{tabular}

Table 2: Grain yield, stover yield and harvest index of bajra hybrids as influenced by iron sources

\begin{tabular}{|c|c|c|c|}
\hline Treatment & $\begin{array}{c}\text { Grain yield } \\
\left(\mathrm{kg} \mathrm{ha}^{-1}\right)\end{array}$ & $\begin{array}{c}\text { Stover yield } \\
\left(\mathrm{kg} \mathrm{ha}^{-1}\right)\end{array}$ & $\begin{array}{c}\mathbf{H I} \\
(\%) \\
\end{array}$ \\
\hline \multicolumn{4}{|l|}{ Hybrids (Main plot) } \\
\hline PBH-1625 & 3766 & 6454 & 36.9 \\
\hline HHB-67 & 2426 & 4727 & 34.0 \\
\hline $\mathrm{SEm} \pm$ & 71 & 168 & 0.5 \\
\hline $\mathrm{CD}(\mathrm{P}=0.05)$ & 466 & 1022 & 2.8 \\
\hline \multicolumn{4}{|l|}{ Iron sources (Subplot) } \\
\hline Control (RDF) & 2789 & 5223 & 34.6 \\
\hline $\mathrm{RDF}+50 \mathrm{~kg} \mathrm{ha}^{-1}$ of $\mathrm{FeSO}_{4}$ applied to soil as basal & 2920 & 5423 & 34.8 \\
\hline $\mathrm{RDF}+\mathrm{FeSO}_{4}$ fortified manure @ $500 \mathrm{~kg} \mathrm{ha}^{-1}$ & 3542 & 6099 & 36.6 \\
\hline $\mathrm{RDF}+\mathrm{FeSO}_{4}$ spray $(0.5 \%$ foliar spray applied two times i.e. before and after flowering) & 3047 & 5508 & 35.6 \\
\hline RDF+ Fe-EDTA spray ( $0.2 \%$ foliar spray applied two times i.e. before and after flowering) & 3182 & 5700 & 35.7 \\
\hline SEm \pm & 83 & 133 & 1.0 \\
\hline $\mathrm{CD}(\mathrm{P}=0.05)$ & 251 & 398 & NS \\
\hline \multicolumn{4}{|l|}{$\begin{array}{l}\text { Hybrids x Iron sources } \\
\end{array}$} \\
\hline \multicolumn{4}{|l|}{ Sub at same main } \\
\hline SEm \pm & 159 & 375 & 1.0 \\
\hline $\mathrm{CD}(\mathrm{P}=0.05)$ & NS & NS & NS \\
\hline \multicolumn{4}{|l|}{ Main at same or different sub } \\
\hline SEm \pm & 127 & 238 & 1.4 \\
\hline $\mathrm{CD}(\mathrm{P}=0.05)$ & NS & NS & NS \\
\hline
\end{tabular}

\section{Conclusion}

On the basis of experimental results, recommended dose of fertilizer along with fortified manure @ $500 \mathrm{~kg} \mathrm{ha}^{-1}$ can be recommended to realise higher yields attributes and yield under rainfed conditions by growing bajra cultivar PBH-1625. Enriched organic source (iron fortified manure) provides iron for plant utilisation and also organic source provided better soil conditions and nutrient availability for higher productivity.

\section{References}

1. ICRISAT. Pearlmillet helps fight iron deficiency: Evidence from three bioavailability studies-ICRISAT. https://www.icrisat.org. 05 may, 2019.

2. World Health Organization. Conclusions and recommendations of the WHO consultation on prevention and control of iron deficiency in infants and young children in malaria-endemic areas. Food and Nutrition Bulletin. 2007; 28:S621-S627.

3. Kedar NR. Biofortified Bajra to fight Iron and Zinc Deficiencies. ICRISAT. https://krishijagaran.com. 28 may, 2019.

4. Samuel PS, Laura EMK, Michael JW, Shobha AU, Padmini SG, Erick boy et al. Cognitive performance in Indian School-Going Adolescents is positively affected by consumption of Iron-biofortified Pearlmillet: A 6month Randomised controlled efficacy trial. Journal of Nutrition. 2018; 148(9):1462-1471

5. Panse VG, Sukhatme PV. Statistical methods for agricultural workers. ICAR, New Delhi, 1978.

6. Yadav Y, Kumar A, Prakash R, Singh R. Phenology and dry matter partitioning in different pearl millet hybrids and composites. Haryana Agriculture University Journal of Research. 2003; 33:119-124. 
7. Kumar S, Kadian VS, Singh RC. Response of pearl millet (Pennisetum glaucum L.) hybrids to row spacing and nitrogen application. Annals of Agricultural Research. 2004; 25(1):68-70.

8. Chaudhari RP, Patel PM, Patel BM, Kumar U, Darji SS, Patel SJ et al. Performance of Summer Pearl Millet (Pennisetum glaucum L.) Hybrids under North Gujarat Conditions. International Journal of Current Microbiology and Applied Sciences. 2018; 7(1):637-644.

9. Prasad SK, Singh MK, Renu Singh. Effect of nitrogen and zinc fertilizer on pearl millet (Pennisetum glaucum) under agri-horti system of eastern Uttar Pradesh. The Bioscan. 2014; 9(1):163-166.

10. Divya G, Vani KP. Cultivars and Integrated Nutrient Management Influence on Summer Pearl Millet. Indian Journal of Pure and Applied Bioscience. 2019; 7(5):5055.

11. Yadav AK, Kumar A, Singh J, Jat RD, Jat HS, Datta A et al. Performance of pearl millet genotypes under irrigated and rainfed conditions at Hisar, India. Journal of Applied and Natural Science. 2014; 6(2):377-382.

12. Bana RS, Pooniya V, Choudhary AK, Rana KS, Tyagi VK. Influence of organic nutrient sources and moisture management on productivity, bioforti- fication and soil health in pearlmillet + cluster bean intercropping system of semi-arid India. Indian Journal of Agricultural Sciences. 2016; 86:1418-1425.

13. Nikhil Kumar, Salakinkop SR. Influence of Agronomic Bio-fortification of Zinc and Iron on Their Density in Maize Grain and Nutrients Uptake. International Journal of Environmental Sciences and Natural Resources. 2018; $7(2): 48-52$

14. Satyajeet, Nanwal RK, Yadav VK, Kumar P. Effect of integrated nutrient management on productivity of pearl millet (Pennisetum glaucum L.) and its residual effect on succeeding mustard (Brassica juncea). Haryana Agricultural University Journal of Research. 2007; 37:1518.

15. Yadav Y, Kumar A, Singh B. Comparative performance of pearl millet hybrids and composites under rainfed conditions. Haryana Agriculture University Journal of Research. 2004; 34:45-47.

16. Bandiwaddar TT, Patil BN. Response of bread wheat (Triticum aestivum L.) to varied levels of iron and zinc enriched with organics in maize-wheat cropping sequence. Karnataka Journal of Agricultural Sciences. 2015; 28(4):467-473. 